\title{
Date despre autori
}

\section{Notice sur les auteur.e.s}

\section{Notes on Contributors}

\author{
https://doi.org/10.52744/9786062613242.24
}

Liliana AGACHE is an Associate Professor Ph.D. at the Faculty of Foreign Languages and Literatures, Dimitrie Cantemir Christian University of Bucharest, and principal researcher III at the "Iorgu Iordan- Alexandru Rosetti" Institute of Linguistics at the Romanian Academy, in the Literary Language and Philology sector. She is a member of research teams on some fundamental projects of the Romanian Academy, such as The Treatise on the History of the Romanian Language, The Corpus of Romanian Notes from the Old Romanian Book from the Romanian Academy's Collections, Popular Old Books, Chrestomathy of the Old Romanian Language (vol. II, III), and a collaborator at the Encyclopedia of Old Romanian Literature. Author of articles, specialized books, and university textbooks, Ms. Liliana Agache has participated in international conferences. Among her fields of interest are literary language, philology, dialectology, contemporary Romanian language, contemporary French language.

Flori BĂLĂNESCU is a graduate of the Faculty of History, University of Bucharest (1994), Postgraduate Sudies (1995); is working on her Ph.D. thesis on the opposition writer Paul Goma; scientific researcher III with the National Institute for Totalitarianism Studies; (co)author of numerous scientific books and studies on the history of communism and more recent history. Among her last books: Grup Canal 77. „Paraziții sociali” şi Mişcarea Goma pentru drepturile omului (Ratio et Revelatio, 2015); Neculai Popa în dialog cu Flori Bălănescu, Fără închisoare, aş fi fost nimic (R\&R, 2016); România 1945-1989. Enciclopedia Regimului Comunist: Represiunea, vol. I-III, 2011-2012-2016 (coord. O. Roske); Ziua care nu se uită. Revolta braşovenilor din 15 noiembrie 1987 (coord. Marius Oprea, Polirom, 2017); Securitatea noastră cea de toate zilele (în dialog cu Cristian Troncotă, Ed. Corint, 2020); Panorama comunismului în România (coord. Liliana Corobca, Ed. Polirom) (forthcoming).

Bouchra BENBELLA est professeure de l'enseignement supérieur à l'université Moulay Ismaïl à Meknès (Maroc) et membre permanent de l'Equipe de recherche : Communication, Interculturel, Patrimoine et Développement Durable à la faculté des lettres et des sciences humaines. Elle a publié plusieurs travaux relatifs au récit de voyage européen au Maroc et à la littérature maghrébine francophone dont les derniers en date, publiés chez l'Harmattan, sont : Najib Redouane. Voix marocaine en Amérique du Nord, (ouvrage collectif sous sa direction, 2021) et Écrivains maghrébins francophones : Tendances esthétiques et culturelles postmodernes (2020).

Onorina BOTEZAT (BA in Philology and Law, MA in Law, Ph.D. in Theory of Literature) is Associate Professor, Director of the Center for Linguistic and Intercultural Research, Dimitrie Cantemir Christian University, Bucharest and 
Editor-in-Chief of the Annals of Dimitrie Cantemir Christian University Linguistics, Literature and Methodology of Teaching. Her main fields of interest and research are Legal Terminology and Imagological Studies. Author of Dictionary of legal terms, Romanian-English and English-Romanian (2011), The image of the foreigner in national literature (2016); Mapping Cultural Identities and Intersections: Imagological Readings (2019, Cambridge Scholars Publishing, co-editor with Mustafa Kirca); co-author of ESP and FSP courses and readers, she has conducted and participated as a team member in ten European research projects.

Dan BURCEA est un critique littéraire français d'origine roumaine, diplômé de l'Université de Bucarest et ancien professeur de lettres. Arrivé en France après la chute du régime communiste, il continue à collaborer avec la presse culturelle roumaine et publie de nombreux articles dans Observator cultural, Suplimentul de cultură, Cultura, Argeș, Dilema Veche, Convorbiri literare. En France, il écrit dans des revues prestigieuses comme La Nouvelle Revue Française (NRF) et le Salon littéraire. Depuis quelques années, il a ouvert un blog d'actualité littéraire, Lettres Capitales, où il a publié jusqu'à présent environ 400 chroniques et interviews avec des écrivains français et roumains. Son seul désir est de promouvoir la littérature, cet « unique miroir en mesure de contenir notre reflet sans se briser », comme le dit si bien un de ses auteurs préférés et ami, Yasmina Khadra.

Ioana CECOVNIUC holds a Degree in English and Spanish, is a graduate of MULTIELE (master of learning and teaching Spanish in international multilingual contexts) at the University of Deusto (Bilbao, Spain), Pompeu Fabra University (Barcelona, Spain) and the University of Groningen (Netherlands). She received her Ph.D. in Philology from Pompeu Fabra University (Barcelona, Spain) and is currently working at the Faculty of Foreign Languages and Literatures, Dimitrie Cantemir Christian University of Bucharest.

Alexandra DODU is a Ph.D. candidate, a French teacher at National College "Şcoala Centrală" and a lecturer at the University of Bucharest. She is interested in 19thcentury women's writings and pre-feminist ideas in the Romanian Principalities; she has subsequently participated and delivered papers at international conferences such as the International Conference on Social Gendered Construction, Bucharest Dimitrie Cantemir University, Periodical Counter Cultures, John Moores University, Liverpool, Les identities dissimulés, Limoges, Spațiu, timp, mentalități, University of Bucharest, and IInd World Literature Congress, University of Louvain. She holds a BA in French and Dutch and a MA in French and Francophone Studies. She also serves as an authorized sworn translator, recognized by the Romanian Ministry of Justice.

Maria-Luiza DUMITRU OANCEA is an Associate Professor Ph.D. at the University of Bucharest's Faculty of Foreign Languages and Literatures, Department of Classical Philology, and Neo-Greek Language. She specializes in ancient Greek, Greco-Roman civilization, and Greek literature (Archaic and Hellenistic Époques). She has delivered papers at conferences and published as author, coauthor, editor, contributor, translator, and reviewer many works on her research interests: Folklore, Greek Literature (Archaic and Hellenistic Époques), Cultural Anthropology, Didactics, Greek Morphology, Greek Syntax. 
Corinne FOURNIER KISS is Privatdozentin at the University of Bern (Switzerland), from which she received in 2017 the venia legendi for French Literature, Comparative Literature and Slavic Literature (triple habilitation). She works with Romance, Slavic and Germanic literatures. Her interests and research areas include Literature and Interculturality, Literature of the Fantastic, Women's Writing, Francophone Literatures, Literature and Music, Literature and Ecocriticism, Literature and the Representations of Space (of cities, borders, landscapes and gardens). Recently, she published the monograph Mme de Staël et George Sand en dialogue avec leurs consœurs polonaises (Presses universitaires Blaise Pascal, Clermont-Ferrand, 2020), edited n. 18 (Special Issue) of the review Pessoa Plural - A Journal of Fernando Pessoa Studies, entitled Fernando Pessoa: Originality and Cosmopolitanism/Originalidade $e$ Cosmopolitismo (Brown University 2020) as well as n. 48 of the review Colloquium Helveticum on Music and Emotions in Literature (Bielefeld, Aisthesis, 2019). She has coedited with Anna Janicka the two volumes on Przemiany dyskursu emancypacyjnego kobiet (Temida, Białystok, 2019) and with Patrick Suter the book Poétique des frontières dans les littératures de langue française (MetisPresses, Geneva, 2021, forthcoming). She was awarded the "Prix Européen du Grand Prix de l'Imaginaire" for her book La Ville européenne dans la littérature fantastique du tournant du siècle (1860-1915) (L’Âge d'Homme, Lausanne, 2007).

Mihaela HRISTEA holds a Ph.D. in Philology (2013). She graduated from the Faculty of Letters, Romanian language and literature - German language and literature at the University of Bucharest. She is the author of The Reception of Heinrich Heine in Romanian literature (2015), Theater im Unterricht (2015), Selected verses (2015) and Metaphor and Symbol in Tudor Arghezi (2015). She currently teaches German language at Dimitrie Cantemir Christian University, "I. L. Caragiale" National College and at "Alexandru Vlahuță” High School in Bucharest.

Maria IROD, Associate Professor Ph.D., Department of Germanic Languages and Literatures of the Faculty of Foreign Languages and Literatures, University of Bucharest, obtained her Ph.D. from the University of Bucharest, with a thesis about a German author from Romania. She had a postdoctoral fellowship at New Europe College in 2016/2017, with a project on dissident Catholic discourse in Germany, after the Second Vatican Council. Author of scientific articles on modern and contemporary German-language literature, she has also published numerous essays, reviews, and translations in cultural magazines (Luceafărul, Lettre Internationale, Deutsch-Rumänische Hefte). Her latest published books are Dieter Schlesak zwischen Moderne und Postmoderne, Frank \& Timme, Berlin 2015 and Josef Winkler - literarische Stillmittel, Wissenschaftlicher Verlag zu Berlin, 2018. Translations: Elfriede Jelinek: Excluşii, Polirom, Iaşi 2005 and Elfriede Jelinek: Lăcomie, Polirom, Iaşi 2008. Areas of interest: intercultural German studies, Austrian literature after 1945, gender studies, religious studies.

Luiza MARINESCU is a comparative literature scholar, specialized in Romanian literary studies, comparative literary studies, and distant reading research. She teaches Romanian Literature at the Faculty of Letters USH Bucharest. Author of more than 100 articles, 10 books, and co-author of more than 30 books, she is a specialist in English and Romanian language and literature. Her main research projects include Umberto Eco novels and semiotics (Ph.D. thesis), Romanian 
novels of the 19th and 20th centuries, medieval Romanian literature, and Japanese literature. She is also one of the first authors of a Romanian literature course for distance learning, of a Romanian language course for foreign students, and was involved in projects on a collection of Ebooks and Epubs of the first Romanian Novels.

Aurora MARTIN, Vice president of the International Institute for Human Security in Chicago; Dean of Faculty of Foreign Languages and Literatures, Dimitrie Cantemir Christian University; Senior advisor in the National Agency for Equal Opportunities between Women and Men. Aurora Martin is an anti-discrimination and gender expert within the Romanian Government and Parliament. She has been coordinator of the Department of Peace Operations, Peace Action, Training and Research Institute of Romania, president of the Euro-Atlantic Partnership for Sustainable Development, editor-in-chief and editor at the Policy's Sphere, Res Publica, Journal of Equal Opportunities and Pro-Diversity. She is a mentor in the Telemachus Global Thinkers program (UK). As a scholarship holder of the US State Department (Professional Fellow Program) she initiated the Mobile Museum of Modern Slavery in Romania. She has been a visiting professor at Wilmington College, Ohio; Russian Presidential Academy of Economics and Public Administration, Saint Petersburg; University of Belgrade; Roma Tre University; Lomonosov State University; Khazar University, Baku; European Center for Security Studies George C. Marshall Germany. In 2015, she was nominated the Woman of the Year in Romania for defending and promoting women's rights. She received awards for the Protection and Promotion of Women's Rights from the Académie Internationale Mihai Eminescu, from the WEF, the Women of the Decade in Security and Conflict Transformation, Award of Excellence \& Recognition from the Egyptian Government and the Iconic Women Creating a Better World for All award. She published: Scienza politica in lingua italiana, ed Transilvania, Braşov, 2005 and Reprezentare identitară feminină în cultura română, ed. Prouniversitaria, Bucureşti, 2018.

Ramona MIHĂILĂ is vice rector for International Relations and full professor Ph.D. at the Faculty of Foreign Languages and Literatures, and director of the Institute for the Social Studies of Gender, Dimitrie Cantemir Christian University, Bucharest, where she teaches undergraduate and graduate courses on literature, women's writing, gender studies. She is the author and (co)-editor of 20 books concerning women's writing and gender studies. She has been visiting professor at Arizona State University, and a research fellow at international institutions: Library of Congress, Washington, Chawton House Library and University of Southampton, Huygens Royal Institute, The Hague, National Library of Vienna. She has received grants for her conference participation from Hogeschool University, Brussels, Université Paris-Est Créteil (among others). She has been coordinator of European projects on gender studies and women's writing. She serves as the executive publishing editor of Journal of Research in Gender Studies, Addleton Academic Publishers, New York.

Alexandra MORARU is a University Lecturer at the Faculty of Foreign Languages and Literatures of Dimitrie Cantemir Christian University, in Bucharest. In 2010 she defended her doctoral thesis at the Al. I. Cuza University of Iasi, in the field of Philology, linguistics, stylistics, and discourse analysis. Since 2001, she has led the English language seminar at the Faculty of International Economic Relations, as 
well as English and French language courses and seminars within the Faculty of Foreign Languages and Literatures.

Claudia MOSCOVICI is the author of the critically acclaimed novels Velvet Totalitarianism (2009) and The Seducer (2011). Velvet Totalitarianism was republished in translation in her native country, Romania, under the title Intre două lumi (Curtea Veche Publishing, 2011). In 2002, she co-founded with Mexican sculptor Leonardo Pereznieto the international aesthetic movement called "postromanticism", devoted to celebrating beauty, passion and sensuality in contemporary art. She wrote a book on Romanticism and its postromantic survival called Romanticism and Postromanticism (Lexington Books, 2007) and taught philosophy, literature and arts and ideas at Boston University and at the University of Michigan. She also published a nonfiction book on predatory relationships, called Dangerous Liaisons (Rowman \& Littlefield Publishing, 2011), which has been translated into Italian under the title Relazioni pericolose (Edizioni Sonda, 2017) and launched at the Italian Parliament. She has recently completed a book of reviews of Holocaust memoirs, novels, histories and films called Holocaust Memories.

Alice NĂSTASE BUCIUTA (BA in Philology and Psycho-sociology, MA in Communication and Ph.D. in Political Sciences) is a Romanian journalist and writer, publisher, and editor-in-chief of Tango-Marea Dragoste and the Publishing House Cărțile Tango, the last publishing house to which the writer Nina Cassian entrusted the re-editing of some of her volumes of poetry and prose, edited the poetry anthology Nina Cassian- O mie de poeme (Editura Cărțile Tango, 2020), is an independent researcher in the field of gender studies and author of several studies on women's publications. She has over 25 years of experience in the media, as a reporter, editor, documentary filmmaker, moderator or television producer. As a writer, she has published 10 books in Romanian novels, essays, collections of interviews or anthologies - and two books in international translations, Avon Book of Love: 13 Years of Passion, Life Stories, Miracles, Love (Humanitas, 2010) and Querer. Probar. Comprar. Cuentos de amor en tiempos de rebajas (Alcala Grupo Editorial, 2014)

Nicoleta Victoria NUȚU is a teacher of Italian at Middle School No 200 in Bucharest. She specialized in English and Italian language and literature at the Faculty of Foreign Languages and Literatures of Dimitrie Cantemir Christian University of Bucharest. Currently she participates in the Master Course in Anglo-American Intercultural Studies at the Faculty of Foreign Languages and Literatures of Dimitrie Cantemir Christian University, working on the dissertation thesis "The Communication before and after Babel." She is the author of the articles "Ambiguity, Symbols and Symmetry in William Blake's Songs of Innocence and Experience - The Lamb and The Tyger" and "From Boccaccio to Chaucer - Themes, Influences and Narratives Shapes" (Literary and Linguistics Studies in Global Journal, ProUniversitaria Publishing House, 2019), co-author with Răzvan Staicu of "Le motivazioni dell'insegnare letteratura, fra atto cultural e spirit critico" and "L'educazione linguistica e l'educazione letteraria, nella didattica dell'italiano insegnato come L2" in Linguistics, Literature And Methodology of Teaching $(2018,2019)$. 
Dan STERIAN holds a Ph.D. in French philology and the field of literary pragmatics, and has twenty years of teaching experience. With a master's degree in Francophone Studies, he is interested in Canadian studies of French expression. As a journalist, he has made over 200 television shows on the national TVH channel, the most famous being the Sunday interviews "French Stories" or the series "French Travels" and "J'aime le français". When not traveling he writes prose, and he is currently working on his first volume of short stories. He has published numerous scientific papers in journals from New York, Montréal, Bucureşti, Iaşi, Chişinău, and has co-authored more then ten universitary readers among which are Le journalisme c'est ma profession, Le français du droit, Discours diplomatique, Aspecte ale civilizațiilor europene, L'entreprise en situation - Discours économique.

Adriana Elena STOICAN (Ph.D. in Literary and Cultural Studies, University of Bucharest) teaches English for Business Communication at the Bucharest University of Economic Studies. She has published articles on Romani identity, Indian diasporic fiction in English, and Romanian literature of migration. She is the author of the book Transcultural Encounters in South-Asian American Women's Fiction, Cambridge Scholars Publishing (2015). Her articles appeared in American, British and Canadian Studies (2016), Between History and Personal Narrative. East European Women's Stories of Migration in the New Millennium, (LIT Verlag 2013), Muses India: Essays on English-Language Writers from Mahomet to Rushdie (McFardland \& Company 2013), The University of Bucharest Review. A Journal of Literary and Cultural Studies, Transnational Literature, e-journal (2016), Synergy, Primerjalna Knjizevnost (Comparative Literature) (2018). 